\author{
Małgorzata Gajak-Toczek \\ ORCID: 0000-0002-9774-887X \\ Uniwersytet Łódzki
}

DOI 10.19195/1642-5782.17(27).2

\title{
O niektórych formach i metodach kształcenia sprawności językowej w ramach ćwiczeń w mówieniu w projekcie Tadeusza Czapczyńskiego
}

Początek XX stulecia ${ }^{1}$ przyniósł rozwój ćwiczeń w mówieniu, które rządziły się innymi prawami niż formy pisemne. Autorzy pierwszego polskiego Programu szkoty powszechnej jednoklasowej czterooddziałowej i dwuklasowej czteroi pięciooddziałowej. Cz. III. Język Polski. Ministerstwo Wyznań i Oświecenia Publicznego z 1918 roku, wprowadzając dział Ćwiczenia językowe ustne i pisemne, zwracali uwagę na znaczenie dla rozwoju człowieka kompetencji posługiwania się polszczyzną w formie mówionej ${ }^{2}$. W istotny sposób rolę ćwiczeń w mówieniu eksponowały programy nauczania języka polskiego z $1934^{3}$ oraz z $1937 \mathrm{roku}^{4}$. Za

${ }^{1}$ W drugiej połowie XIX wieku nauka o języku miała charakter normatywny i wskazywano związek między nauczaniem gramatyki a umiejętnością posługiwania się językiem. Zmianę w zakresie kształcenia sprawności językowej przyniosła praca zbiorowa Prądy w nauczaniu języka ojczystego, red. S. Szober, Warszawa 1908.

2 Ćwiczenia w mówieniu miały pomóc uczniowi w językowym logicznym ujmowaniu tego, co czytał, widział i przeżył; por. Program szkoty powszechnej jednoklasowej czterooddziałowej i dwuklasowej cztero- i pięciooddziałowej. Cz. III. Język Polski. Ministerstwo Wyznań i Oświecenia Publicznego, Warszawa 1918, s. 53.

3 Autorzy w porównaniu do wcześniejszego programu postawili inaczej akcenty w zakresie celów nauczania języka polskiego: „nauka tego przedmiotu ma dać młodzieży tak podstawowe dobro kulturalne jak znajomość i opanowanie mowy ojczystej, a więc zespół nieodzownych środków wypowiadania się i porozumiewania”; Program nauki w publicznych szkołach powszechnych trzeciego stopnia z polskim językiem nauczania (tymczasowy). Ministerstwo Wyznań i Oświecenia Publicznego, Lwów 1934, s. 28.

4 Program nauki w państwowym liceum ogólnokształcacym z polskim językiem nauczania (tymczasowy). Język polski, Lwów 1937. 
nowatorski należy uznać postulat oparcia ćwiczeń ustnych nie tylko na lekturze, lecz także na codziennych doświadczeniach ucznia i jego zainteresowaniach. Sytuowanie celów edukacyjnych bliżej wychowanka podyktowane było pojawieniem się w psychologii i pedagogice prądów akcentujących indywidualność każdej jednostki, podkreślających konieczność poszanowania jej praw do swobodnego rozwoju, które powinny być uwzględniane zarówno w doborze metod, jak i w treściach kształcenia ${ }^{5}$.

Podobne stanowisko prezentowali nauczyciele i pisarze: Juliusz Balicki, Franciszek Bielak, Tadeusz Czapczyński ${ }^{6}$, Jadwiga Dańcewiczowa, Jan Dżugaj, Henryk Gaertner, Wawrzyniec Galant, Jadwiga Jonganówna, Juliusz Kaden-Bandrowski, Michał Kędzior, Juliusz Kijas, Zenon Klemensiewicz, Jan Kulpa, Wanda Kwaskowska, Kazimierz Okrzański, Władysław Szyszkowski . W licznych publikacjach omawiali wyniki własnych eksploracji, przedstawiali rezultaty prowadzonych badań, jak też zgłaszali konkretne rozwiązania metodyczne. Do pracy naukowej zachęcali innych. Edukacji nie traktowali jako procesu biernego, pole-

5 Podstawy psychologiczne i językowe oraz rolę ćwiczeń w mówieniu i pisaniu szeroko omówiła J. Dańcewiczowa, Dydaktyka mówienia i pisania jako działu nauczania języka ojczystego, [w:] Encyklopedia wychowania, t. 2, Warszawa [1936], s. 290-299. A. Urbański konstatował: „By sobie zapewnić zainteresowanie się ze strony uczniów, nauczyciel musi umieć trafiać do umysłowości dzieci poprzez traktowanie materiału z punktu widzenia egocentryzmu dziecka. Sprawy, dla których dziecko nie ma zrozumienia, z którymi nie styka się uczuciowo w życiu, pozostają dla niego obojętne, choćby, widziane oczyma człowieka dorosłego, przedstawiały wartości wysokie i zasadnicze” —idem, O lepsze wyniki ćwiczeń w mówieniu, „Przyjaciel Szkoły” 1937, nr 16, s. 633.

6 T. Czapczyński (ur. 1884 we Lwowie, zm. 1958 w Łodzi) — polonista, badacz literatury i twórca. U progu niepodległości przedstawił model heurystycznego poznawania dzieła literackiego na przykładzie Pana Tadeusza A. Mickiewicza $(1920,1922,1925)$ oraz Ogniem i mieczem H. Sienkiewicza (1922). Autor wielu studiów literackich — między innymi Twórczość powieściopisarska Józefa Weyssenhoffa (jednostronna analiza wewnętrznej konstrukcji), [w:] Sprawozdanie dyrekcji gimnazjum realnego żeńskiego Sióstr Urszulanek w Stanisławowie z prawem publiczności w myśl reskr. Min. W. i O. z 16 maja 1914, L. 18574 oraz Szkoły Pospolitej i Liceum 7-klasowego za rok szkolny 1913/14, Stanisławów 1914, s. 3-45; Marian Piechal (1937); Ze studiów nad pieśniq o Pitsudskim (1939); prac biograficznych ad usum scholarum — Walerian Łukasiński (1913), Aleksander Fredro (1947), Hugo Kołłątaj (1948)] oraz artykułów metodycznych — Lekcja metodyczna: „Gtupi Franek” Konopnickiej, „Muzeum” 1922, z. 2, s. 123-150; Pierwszy ustęp w klasie pierwszej szkoty średniej (cz. II), „Przyjaciel Szkoły” 1924; nr 14, s. 296-300), szkiców na temat dorobku Marii Dąbrowskiej i Marii Konopnickiej oraz niewydanej monografii tej ostatniej. Był także popularyzatorem dorobku romantyków oraz autorem własnych wierszy — Pamiętam... Poezje, 1937 i książeczek dla dzieci - Książeczka trochę nowa, trochę stara o Magdzie, mące, kluskach i zegarach, 1942; Idzie sobie bobas maty, 1948). Zob. S. Skwarczyńska, Tadeusz Czapczyński (1884-1958), „Prace Polonistyczne" 1960, seria 16, s. 229-232; B. Bogołębska, Czapczyński Tadeusz (1884-1958), [w:] Słownik badaczy literatury polskiej, red. J. Starnawski, Łódź 1994, s. 55-61; J. Czachowska, Czapczyński Tadeusz, [w:] Współcześni polscy pisarze i badacze literatury. Słownik biobibliograficzny, oprac. J. Czachowska, A. Szałagan, t. 2, Warszawa 1994, s. 80-82; M. Gajak-Toczek, Tadeusz Czapczyński. Pedagog - literaturoznawca - literat, Łódź 2017.

7 Por. W. Szyszkowski, Bibliografia metodyki nauczania języka polskiego 1918-1939, Warszawa 1963, s. 88-92. 
gającego na przekazywaniu wiedzy z zewnątrz do wewnątrz, jej transferze z podręcznika lub głowy nauczyciela do głowy ucznia.

\section{Pozwólmy uczniom mówić}

Czapczyński ćwiczenia w mówieniu traktował jako samodzielny dział nauczania $^{8}$. Ich celem było osiągnięcie przez ucznia „,poprawnego, biegłego, jasnego i bogatego, a przy tym samodzielnego, a zatem również indywidualnego wyrażania się w mowie" $"$.

Akcentując podmiotowy charakter edukacji, punktem wyjścia czynił dziecko, jego zainteresowania i świat uczuć, by w ten sposób zintensyfikować i wzbogacić zdolność przeżywania ${ }^{10}$. $\mathrm{Z}$ pasją pisał: „cała dusza jego może się w nich [ćwiczeniach w mówieniu - M.G.-T.] odzwierciedlić”. I dodawał, że dzięki ćwiczeniom w mówieniu

nauczyciel może zorientować się w typach wyobraźni, pamięci, uwagi, w reakcji uczuciowej swych uczniów, poznać bogatą dziedzinę ich pragnień, postanowień, motywów działania. Świat moralny ucznia, zamiłowania estetyczne, zapatrywania społeczne i polityczne przemówią do nas głosem żywym, niekłamanym, nieprzytłoczonym ciężarem tylko narzuconych mu treści. (ĆW, 18)

Mówienie o tym, co wypływało z codziennych doświadczeń, angażowało jego zdaniem - wychowanka, było czynnikiem, który pozwalał na przezwyciężenie oporów wynikających z konieczności nazywania spraw odległych, mało lub w ogóle wcześniej nieznanych ${ }^{11}$.

Świadomie organizowane i planowo przeprowadzane ćwiczenia w mówieniu powinny pojawiać się w różnych fazach zajęć. Powiązane z pracą domową służyły w pierwszej części lekcji zarówno powtarzaniu materiału, jak i „przygotowaniu i wprowadzaniu" nieznanych kwestii. W części końcowej, gdy dokonywano rekapitulacji przedstawianych zagadnień, stanowiły „dowód przyswojenia sobie nowych wartości i związania ich z dawnymi wiadomościami”. Znacznie bowiem łatwiej uczyć się nowego, gdy wyrasta ono z istniejących, utrwalonych już do-

8 Podręczniki do kształcenia językowego szerzej omówiłam w artykule Język domostwem bycia - o funkcjonalnym nauczania polszczyzny w podręcznikach dla nauczycieli Tadeusza Czapczyńskiego, „Kształcenie Językowe” 16, 2018, s. 9-28.

9 T. Czapczyński, Ćwiczenia w mówieniu. Przyczynek do metodyki języka polskiego, Warszawa 1922, s. 14, dalej: skrót ĆW i numer strony.

10 Czapczyński za podstawę wszelkich działań nauczyciela uznawał „poznanie psychiki dziecka, a zwłaszcza zainteresowań uczniów i uczennic od 10 do 18 roku życia” — ĆW, 17.

11 Czapczyński notował: ,[...] dookoła zaś ucznia rozwija się bujne, wszechstronne, ruchliwe życie, wrące tysiącem nowych zagadnień, których mu nie rozwiążą ani lekcje przyrody, ani geografii, ani nawet historii, choć ta obok religii ma najwięcej pola aktualizowania. Na te wszystkie pytania, dotyczące stosunku budzącej się jednostki do jak najszerzej pojętego otoczenia, jednostki, która w swym rozwoju przeżywa nowe odkrycia, rzeczy dawno już przez nas odkrytych, muszą dać odpowiedź ćwiczenia w mówieniu, by zadość uczynić wymaganiom programu, który żąda wychowania człowieka i obywatela" - Ć́W, 16. 
świadczeń. Mogły one też tworzyć „podstawową, główną część lekcji”, poprzedzoną „odpowiednim wprowadzeniem, przygotowaniem, a zakończoną skupieniem i zastosowaniem" (ĆW, 116).

\section{Formy ćwiczeń w mówieniu}

W przezwyciężaniu sztuczności lekcyjnego aktu komunikacyjnego, w czasie którego nauczyciel jako kontrolujący i oceniający stawiał pytania nie po to, by się czegoś dowiedzieć, lecz rozpoznać stan wiedzy podopiecznego, pomocą służyły zróżnicowane działania polonistyczne. Inicjowane na zajęciach, miały wzbogacać słownictwo ucznia, pomagać w nazywaniu otaczającego świata, rozszerzać krąg jego zainteresowań na zagadnienia bardziej odległe, uczyć poprawnej artykulacji, operowania możliwościami głosu, wspierania odpowiedzi swobodnym gestem czy mimiką. Pozwalając młodzieży „wypowiadać swobodnie, samodzielnie to, co jest najważniejszą i najgłębszą treścią jej duszy”, Czapczyński przekonywał, że „forma, której szuka sobie treść, staje się istotną zdobyczą, własnością niepodzielną ucznia; im bogatsza będzie treść, tym bogatszego szukać będzie dla siebie wyrazu na zewnątrz" (ĆW, 14).

„Do ulubionych ćwiczeń” (ĆW, 85) gimnazjalistów zdaniem łódzkiego pedagoga należały swobodne wypowiedzi ${ }^{12}$. Dotyczyły one wydarzeń z życia klasy i szkoły, pierwszego dnia po wakacjach, wycieczek krajoznawczych ${ }^{13}$, sposobów spędzania wolnego czasu ${ }^{14}$ oraz lektury ${ }^{15}$. Wychowankowie powinni mówić o tym, co im się podobało bądź wywoływało niezadowolenie, przedstawiać swoje radości i smutki, zachwyty i zmartwienia. $Z$ czasem wypowiedzi mogły przechodzić w bardziej złożoną postać: dłuższego opowiadania o rozmaitych sytuacjach, opisu miejsca, zabytków, sprawozdania z wydarzeń, w których brali udział bądź sprawozdania z lektury. Postępując w ten sposób, młodzi ludzie przełamywali herbartowski werbalizm, wdrażali się do kojarzenia różnorodnych słów, operowania

12 Zaznaczmy, że określenie to zakładało zarysowanie jedynie pewnych ram treściowych wypowiedzi, a nie stawiało konkretnego zadania do rozwiązania.

13 T. Czapczyński pisze: „Wycieczki, jako najbardziej odpowiadające młodzieży przez swój charakter zaspokajający ruch i ciekawość, zjawiają się w przeróżnej formie: Wycieczka zastępu, wycieczka harcerska, wycieczka geograficzna (nad Narew), przyrodnicza, do lasu, po mieście, do garncarza, na górę [...], na wieś, gimnastyczna, majówka w lesie" - ĆW, 39.

14 By poznać zainteresowania młodych ludzi, Czapczyński przeprowadził wśród młodzieży pułtuskiej ankietę, którą objął 379 chłopców Męskiego Gimnazjum im. P. Skargi i 210 dziewcząt Żeńskiego Gimnazjum im. K. Potockiej. Respondentom postawił 10 pytań. Uczniowie preferowali zdecydowanie gry ruchowe (piłkę nożną, palanta, jazdę konną, zabawę w wojsko), natomiast uczennice wybierały zajęcia spokojne (śpiew, muzykę, bawienie się w dom) - ĆW, 45-46, 67-69.

15 T. Czapczyński nawiązywał do pozycji: M. Reiter, Czytania polskie (kl. I-III), Lwów 19101912; F. Próchnicki, K. Wojciechowski, Wypisy polskie dla szkót średnich, Lwów 1911 (k1. IV-V); I. Chrzanowski, K. Wojciechowski, Wypisy polskie dla klas wyższych szkót średnich (k1. VIIVIII), Lwów 1913. 
urozmaiconymi konstrukcjami językowymi, budowania dłuższych wypowiedzi, odbijających się żywym echem w świadomości słuchaczy, dla których były ćwiczeniami w rozwijaniu wyobraźni ${ }^{16}$. W przekonaniu Czapczyńskiego nauczyciel powinien być świadomy właściwych mowie żywej (jednoczesność myślenia i mówienia) zaburzeń semantycznej i syntaktycznej spójności wypowiedzi, występowania pauz, powtórzeń, wtrąceń, obecności ekspresywizmów. Miał „cierpliwie i z sympatią słuchać”, a swoją postawą, głosem, mimiką „,do opowiadań zachęcać, czasem ułatwiać, czasem zapytać"17. Takie zachowanie przynosiło cenne z pedagogicznego punktu widzenia korzyści: umożliwiało poznanie zespołu klasowego, zainteresowań i światopoglądu podopiecznych. „A kiedy nauczyciel pozwoli im otworzyć usta i swobodnie się wypowiadać — zauważał łódzki dydaktyk — wyspowiadają się szczerze ze swych upodobań, zamiłowań, zdadzą sprawę z dziesiątek spostrzeżeń, doświadczeń, odkryją swoje uczucia, okażą pragnienia i chęci"18. Ideę Czapczyńskiego dwa lata później propagował na I Ogólnopolskim Zjeździe Polonistów Ryszard Skulski ${ }^{19}$.

Wskazywanie zalet i braków wypowiedzi miało następować — podobnie jak w pierwszej instrukcji programowej do kształcenia polonistycznego Franciszka Próchnickiego ${ }^{20}$ - po zakończeniu wypowiedzi. W dalszej części lekcji porządkowano pozyskane uwagi, tak by mogły one tworzyć fundament do realizowania nowego tematu.

Funkcjonowanie swobodnych wypowiedzi, wspartych na indywidualnych doświadczeniach uczniów, zaprezentował Czapczyński w artykule Pierwszy ustęp w klasie pierwszej ${ }^{21}$. Wakacyjne wspomnienia miały służyć przełamywaniu strachu przed nowymi obowiązkami i ułatwiać aklimatyzację w szkolnej rzeczywistości. Łódzki dydaktyk przestrzegał jednak przed formułowaniem zbyt ogólnych tematów (na przykład Moje wakacje), sugerując, by przybierały one postać „ściśle ograniczonej i zindywidualizowanej” formuły: Najprzyjemniejszy dzień w czasie wakacji; Dzień słoneczny; Niepogoda; Nieznośny deszcz (ĆW, 86). Pogłębieniu aktu lekturowego czytanek Życie szkolne w dawnych czasach, Garnuszek paupra,

16 Aspekt ten uwypuklają współcześnie M. Kuziak i S. Rzepczyński, pisząc: „Ludzie od najdawniejszych czasów chętnie słuchali opowieści, które poszerzały ich wiedzę o świecie, pozwalając im w ten sposób przekraczać próg przestrzeni ich aktywności, oczekiwali nie tylko wiernej (realistycznej) relacji, ale także tematów dotyczących niezwykłości, cudowności, dziwności itp. Tak więc słuchanie opowieści nie tylko wypełniało czas, ale zaspakajało ciekawość świata i ludzi" — eidem, Jak pisać?, Bielsko-Biała 2005, s. 42.

17 Ibidem.

18 T. Czapczyński, Pierwszy ustęp..., nr 14, s. 296.

19 R. Skulski, Ćwiczenia w mówieniu jako postulat ogólnopedagogiczny w szkole średniej, [w:] Pamiętnik I Ogólnopolskiego Zjazdu Polonistów w Warszawie w dniach 24, 25, 26 kwietnia 1924 r., oprac. W. Kopczewski, Lwów-Warszawa 1925, s. 103.

20 F. Próchnicki, Wskazówki do nauki języka polskiego, Lwów 1885, s. 41. Zob. również M. Gajak-Toczek, Franciszek Próchnicki (1847-1911) dydaktyk - edytor - badacz literatury, Łódź 2010, s. 51-52.

21 Por. T. Czapczyński, Pierwszy ustęp..., nr 13, s. 270-272; nr 14, s. 296-300. 
Dawid $i$ Goliat, dotyczących życia szkolnego, służyć miały wypowiedzi na tematy: Dlaczego się uczę; Komu zawdzięczam możność zdobycia wiedzy i moje wobec nich obowiazki; Do czego potrzebni sa ludzie wyksztatceni? ${ }^{22}$

Swobodne wypowiedzi popierali również inni nauczyciele. Warto przywołać stanowisko Jana Dżugaja, który wskazując znaczenie pogawędki na temat imion i nazwisk dzieci już w pierwszej klasie szkoły podstawowej, zaznaczał, że jest ona „fundamentem, na którym oprzemy cały nasz późniejszy dorobek w zakresie ćwiczeń w mówieniu" 23.

Łódzki polonista dostrzegał także edukacyjną wartość rozmowy, czyli ukierunkowanego sposobu wypowiadania się na ściśle określony temat, który powinien interesować młodzież. Planowa rozmowa polegała na wyjaśnianiu różnorodnych spraw, uzyskiwaniu stosownych informacji oraz uściślaniu wyrazów i pojęć. Właściwie prowadzona, pobudzała aktywność ucznia, mobilizowała do językowej poprawności, zwięzłości i precyzji, segregowania posiadanych wiadomości zgodnie z pytaniami zadanymi przez nauczyciela. Ciekawość poznawczą wzmacniała dodatkowo możliwość stawiania pytań przez uczniów. Te ostatnie powinny być jednoznaczne, zrozumiałe, prawidłowo sformułowane. Wyrażając myśli w związku z omawianym tematem, młodzi ludzie uzupełniali swoje wypowiedzi, prostowali błędne, pytali o sprawy pominięte, prosili o dodatkowe wyjaśnienia, dodawali nowe szczegóły, posługując się zróżnicowanymi składniowo konstrukcjami (zdania pojedyncze, złożone, równoważniki zdań, niekiedy pojedyncze słowa). Rolą nauczyciela było wydobywanie i podkreślanie kwestii istotnych dla omawianego zagadnienia, a tłumienie tych, które miały charakter dorywczo-asocjacyjny ${ }^{24}$. Przykładowe tematy wolne, dla których czytanka Dobra stużba stanowiła jedynie inspirację, brzmiały: Co to jest szczęście moim zdaniem?; Kiedy bym uważat się za szczęśliwego?; Dlaczego bogactwo nie daje szczęścia? (ĆW, 84).

Czapczyński, wiedziony bardzo dobrym wyczuciem rzeczywistości szkolnej, nie rezygnował ze streszczenia lektur ${ }^{25}$. Niemniej formie tej - w przeciwieństwie do dawnej szkoły - nie przyznawał dominującego znaczenia. Zdawał sobie jednak w pełni sprawę z dydaktycznych korzyści tego typu ćwiczeń. Transformacja tekstu polegała na jego skróceniu przy zachowaniu zasadniczych elementów struktury i idei (najważniejsze treści, problemy sylwetki bohaterów). Przy redagowaniu streszczenia uczeń miał kierować się zasadą „minimum słów, maksimum treści”. Szczególnie istotną umiejętnością była zdolność do konden-

22 Pytania te stanowiły jedynie inspirację dla polonistów; zgodnie z zasadami swobodnej wypowiedzi nie musiały się pojawić na lekcji.

23 J. Dżugaj, O ćwiczeniach w mówieniu, „Przyjaciel Szkoły” 1931, nr 9, s. 348.

24 W. Kwaskowska proponowała lekcyjną rozmowę, poza wspomnieniami wakacyjnymi, opowiadała się za skoncentrowaniem uwagi młodzieży na kwestiach przeprowadzanej wówczas reformy oświatowej; por. eadem, Jak realizowałam ćwiczenia w mówieniu i pisaniu, „Polonista” 1937, s. 46-49.

$25 \mathrm{~W}$ praktyce szkolnej tworzenie streszczeń poprzedzone było budowaniem rozwiniętego planu. 
sowania informacji. Streszczenie służyło wspomaganiu procesu zapamiętywania i uczyło uważnego czytania.

Aktywizacji procesów psychicznych służyły lekcyjne dyskusje. Ich prawidłowy przebieg gwarantowała znajomość zasad organizujących zbiorową wymianę myśli. Problem koncentrujący uwagę uczniów należało rozwiązać w toku zdyscyplinowanej rozmowy. Dyskusja uczyła wymiany argumentów, obrony własnego stanowiska, opierała się na logice argumentowania, uzasadniania własnych sądów i opinii, prowadzenia polemiki, formułowania wniosków, domagała się precyzji, zwięzłości i logiki wypowiedzi ${ }^{26}$. Wprowadzeniem do niej mogły być tezy przedstawione przez prowadzącego zajęcia lub formy referatowe w starszych klasach. $\mathrm{Z}$ pewnością ujmowaniu spraw z różnych stron służyły refleksje wokół tematów: Co uczeń zawdzięcza ojczyźnie?; Jak się może przejawiać mitość ojczyzny u poszczególnych stanów (cechy wspólne, różne)?; W jaki sposób dawni Polacy okazywali swa miłość dla ojczyzny?; Jaki powinien być stosunek obywatela do rzadu? (na podstawie czytanki O miłości ojczyzny [ĆW, 93]). Można było także w ramach aktualizacji treści nawiązywać do wydarzeń współczesnego życia (na konieczność stosowania takich zabiegów wskazywały wyniki ankiety przeprowadzonej przez Czapczyńskiego wśród pułtuskich gimnazjalistów, którzy odznaczali się małą wiedzą na temat ówczesnych przemian politycznych [ĆW, 45-69]).

Sprawozdanie umożliwiało z kolei relację z różnych wydarzeń z różnych bieżących wydarzeń. Zadaniem uczniów było możliwie najdokładniejsze, zwięzłe, ścisłe i rzeczowe przedstawienie jakichś wydarzeń, wypadków, faktów i ich okoliczności, z uwzględnieniem następstwa czasowego (Przyjazd generała Hallera do Puttuska; Jak Niemcy uciekali z Puttuska; Wrażenia z pobytu w Rosji; Lekcje rysunków na świeżym powietrzu, nad rzeka, w ogrodzie).

Za najbardziej popularną formę wypowiedzi ustnej autor Ćwiczeń $w$ mówieniu... uznał opowiadanie ${ }^{27}$. Jego zasadniczymi cechami były: czasowe następstwo wydarzeń (kiedy?), różne miejsca (gdzie?), akcja (co się działo?), łańcuch przyczynowo-skutkowy wydarzeń zachodzących w określonym czasie i w określonych okolicznościach (jak to było?). Ważnymi elementami opowiadania stawali się także bohaterowie (kto?). Dla werbalnej reprezentacji rzeczywistości istotne znaczenie miały ponadto dwie konstytuanty: zmiana i przekształcenie akcji. W młodszych klasach Czapczyński zalecał tworzenie opowiadań z uwzględnieniem porządku chronologicznego, w późniejszych dopuszczał formy trudniejsze o kompozycji przestawnej. Na kształcenie sprawności komunikacyjnej składały się takie elementy, jak: język, osobowość nadawcy i odbiorcy komuni-

26 Podobne stanowisko zajął R. Skulski, op. cit., s. 107.

27 Dziś w poradnictwie dydaktycznym zauważa się szczególną rolę opowiadania, na przykład M. Kuziak i S. Rzepczyński piszą: „Opowiadanie to jedna z najstarszych form komunikowania się ludzi. Jest relacją ze świata zdarzeń i odnajdujemy tę formę w najstarszych zachowanych tekstach kultury, np. w eposach Homera, Biblii, w Mahabharacie czy w średniowiecznych eposach rycerskich" - eidem, op. cit., s. 42. 
katu, obszar wspólnej wiedzy o świecie, kontekst, w którym dochodziło do komunikacji, oraz cele stawiane sobie przez interlokutorów. Wyczulenie na te aspekty komunikowania się miało (ma) doniosłe znaczenie społeczne.

Ze względu na temat Czapczyński wyróżniał opowiadania: 1. odtwórcze na podstawie lektury; 2. twórcze (na tej samej podstawie) - aktywizowały one umysłowo podopiecznych, rozwijały wyobraźnię i fantazję, dowodziły znajomości (bądź jej braku) lektury; 3. twórcze na podstawie doświadczeń życiowych dzieci, obrazujące naturalną potrzebę wypowiedzenia się, uzewnętrznienia swych myśli i uczuć. Pierwszy typ reprezentowały między innymi opowiadania o życiu Słowian w nawiązaniu do czytanki Świętowita pogrom (kl. III) czy odtworzenie ludowego podania na przykładzie Mickiewiczowskiej Świtezi (kl. III), drugi tematy: Dalsze losy Andrzeja Radka (bohatera powieści Stefana Żeromskiego Syzyfowe prace); Dalsze losy kottowego (bohatera opowiadania Marii Konopnickiej $D y m)$. Tu umieścić można również opowiadania ze zmianą formy gramatycznej (na przykład przejście z pierwszej osoby na drugą) oraz treści (wprowadzanie innych punktów widzenia, okoliczności zdarzeń itp.), takie jak: opowiadanie jednego z rycerzy o powstaniu Gniezna (na motywach czytanki Założenie Gnie$z n a$, kl. I), opowiadanie jednego z braci o swoich doznaniach (czytanka Miłość braterska, kl. I) czy opowiadanie mecenasa lub niewidomej, bogatej dziewczynki (Katarynka Bolesława Prusa). Do trzeciej grupy można zaliczyć propozycje: rozwinięcia puenty bajki Pawet i Gawet Aleksandra Fredry: Jak ty komu, tak on tobie (kl. I) oraz wykreowania w nawiązaniu do czytanki Skapiec antytetycznego obrazu człowieka pożytecznego. Formy te na plan pierwszy wysuwały „,inteligencję ucznia, bogactwo wyobraźni, zabarwienie uczuciowe, zamiłowania, nie mówiąc o tym, że materiałem głównym [była - M.G.-T.] zdobyta umiejętność spostrzegania, doświadczenia, praktyka życiowa" (ĆW, 84). W tym miejscu należy jeszcze zwrócić uwagę na tematy upominające się o relacjonowanie przeżyć, na przykład Co odczuwałem, kiedy ojciec ze wsi do mnie przyjechat?; Co czułem, kiedy źle odpowiadatem w klasie? Wiele okazji do tworzenia twórczych opowiadań nasuwały „tematy patriotyczne, cierpienia narodu, walka o wolność" (ĆW, 84; na przykład opowiadanie o walkach żołnierzy na frontach Europy, pobycie w niewoli, powrocie do domu).

Samodzielną dłuższą formą wypowiedzi w rzeczywistości szkolnej — oprócz opowiadania — był opis. Jego zadaniem było ujęcie charakterystycznych i wyróżniających cech opisywanego przedmiotu, grupy przedmiotów, zjawisk, krajobrazu, wnętrza, sytuacji współistniejących w tym samym czasie i przestrzeni. Mógł także odnosić się do postaci. Wymagał umiejętności obserwacji, skupienia uwagi na detalu (w zależności od ćwiczenia należało na przykład wyodrębniać kształt, wielkość, nazywać kolor, materiał, z którego przedmiot był wykonany, określać ciężar, zapach, wskazywać jego przeznaczenie), posługiwania się zróżnicowanym, dostosowanym do poruszanej kwestii słownictwem, określenia własnego stosunku do tematu wypowiedzi. Mógł mieć charakter statyczny lub dynamiczny. Opis 
obligował do stosowania zróżnicowanych konstrukcji czasownikowych (wprowadzania czasu teraźniejszego, strony biernej czy też form nieosobowych) oraz posiłkowanie się wyrazami oznaczającymi stosunki przestrzenne. Słownictwo radził Czapczyński gromadzić i zapisywać, na przykład podczas swobodnych wypowiedzi dzieci lub w czasie sporządzania planu wypowiedzi. Przekonywał ponadto, że czytankowy opis domu szlacheckiego może zainicjować opis „domu, mieszkania ucznia, a nawet ciekawe projekcje świadczące o marzeniach dziecięcych: np. jakbym chciał urządzić sobie gospodarstwo, dom, mieszkanie" (ĆW, 82). Łódzki pedagog za stosowne uważał zachęcanie wychowanków zarówno do opisywania pracy rodziców, znajomych, rozmaitych rzemieślników (ostatnią pracę należało połączyć z wycieczkami do warsztatów i fabryk), jak też ich samodzielnego udziału w domowych czynnościach. Należało opisywać najbliższą okolicę, naturę (elementy edukacji regionalnej), obrazy i zabytki architektoniczne (w tym zakresie edukacja patriotyczna zespalała się z edukacją kulturową).

W propozycji Czapczyńskiego nie zabrakło również charakterystyki indywidualnej, zbiorowej i porównawczej. Do żelaznych zasad łódzki dydaktyk zaliczył prezentację postaci (kim jest?), przybliżenie okoliczności spotkania, zamieszczenie uwag na temat jej wyglądu (wzrost, budowa ciała, kształt i rysy twarzy, włosy, oczy, nos, usta itp.; ogólne wrażenie, na przykład elegancki, sympatyczny, budzący zaufanie), charakteru (stosunek do innych ludzi, samego siebie, przyrody, poglądy i ideały życiowe), usposobienia (na przykład flegmatyczne, kapryśne, koleżeńskie, optymistyczne, łagodne, gwałtowne, nerwowe). Podsumowanie powinno zawierać opinie i przemyślenia ucznia na temat prezentowanej postaci. Czapczyński proponował tworzenie charakterystyk kolegów, rodziców, bohaterów literackich i postaci historycznych. Mianowicie na przykład czytanka Pogrzeb Kościuszki wywołać mogła „zagadnienia roli, jaką spełniają wielcy ludzie w narodzie” (ĆW, 92). Za ważne Czapczyński uznawał przybliżenie w czasie lekcyjnego dyskursu dokonań postaci współczesnych: Józefa Piłsudskiego, generała Józefa Hallera, Ignacego Paderewskiego, Wincentego Witosa, Wojciecha Korfantego ${ }^{28}$.

Wprowadzenie do lekcyjnej empirii „mowy, czyli przemówienia” stanowiło nawiązanie do dawnej tradycji ars oratoria. Mowa, nastawiona głównie na funkcję impresyjną, posługiwała się różnorodnymi chwytami retorycznymi: opisem faktów, techniką exemplum, argumentami mającymi przekonać słuchaczy do prezentowanego stanowiska oraz kontrargumentami, które stanowiły polemikę z przewidywanymi argumentami przeciwnika i spodziewanymi zarzutami. Czapczyński przestrzegał przed wypowiadaniem się na tematy odległe dla mówcy, takie, które go nie zajmują. Przemówienia miały dotyczyć spraw aktualnych (na przykład $\mathrm{Za}$ dania, jakie spoczywaja na młodych Polakach $w$ wolnym kraju; Idee samopomocy uczniowskiej; Działalność samorządu szkolnego) oraz kwestii literackich (na

28 Na pytanie „Kogo z Polaków uważam za największego?” w ankiecie przeprowadzonej przez Czapczyńskiego chłopcy wskazywali: Piłsudskiego (52,2\%), Hallera (40,9\%), Paderewskiego (11,8\%); dziewczynki: Piłsudskiego (43,8\%), Hallera (41,4\%), Paderewskiego (8\%) — ĆW, 54-55. 
przykład Ocena postępowania tytułowego bohatera powieści poetyckiej Juliusza Stowackiego - Jana Bieleckiego; Ocena Mickiewiczowskiego Konrada Wallenroda). Przeciwny był również praktykom słownej manipulacji.

Referaty łódzki pedagog kierował do uczniów starszych klas. Ich charakter był różnorodny: obejmowały zagadnienia związane z jednym utworem, stanowiły syntezę twórczości pisarza czy dokonań epoki, wreszcie zawierały elementy komparatystyczne. Wymagały od wychowanków samodzielnych poszukiwań w literaturze przedmiotu, selekcji materiału, uporządkowania kompozycyjnego i estetycznego wygłoszenia.

\section{Od strony praktycznej}

Rozważania tej części warto rozpocząć ustaleniami dotyczącymi sposobu pojmowania metody. Trzeba jednak zaznaczyć, że dydaktyka polska nie wypracowała jednoznacznej i spójnej definicji pojęcia. Najczęściej oznacza ono świadomy, możliwy do powtarzania w podobnych sytuacjach sposób postępowania nauczycieli, który ma prowadzić poprzez logicznie powiązane i uporządkowane sekwencje czynności do realizacji treści przedmiotowych, umożliwiających wychowankowi kształtowanie świata wartości i jego wszechstronny rozwój (aspekt podmiotowy $)^{29}$. Dobór metody uzależniony był (i jest) od czynników ogólnych — przyjętej filozofii nauczania (system i koncepcje dydaktyczne, założenia teoretyczne, leżące u podstaw procesu), stanu wiedzy dyscyplin macierzystych i dydaktyki przedmiotowej, rozwoju nauk pedagogicznych i psychologicznych, oraz indywidualnych — założonego celu lekcyjnego, predyspozycji nauczyciela i możliwości ucznia. Dodajmy jeszcze, że — podobnie jak ma to miejsce dzisiaj ${ }^{30}$ w dwudziestoleciu międzywojennym używano wymiennie pojęć: metoda, forma, system $^{31}$.

Ćwiczenia sprawności językowej Czapczyński (a stanowiło to postulat nowatorski) opierał na praktycznej działalności uczniów, która angażowała zarówno ich intelekt, jak i emocje. W szczególny sposób wyróżniał cztery metody, które zostaną przybliżone w dalszej części artykułu: przekład intersemiotyczny (choć nie posługiwał się tym terminem), działania, które dziś określilibyśmy mianem dramy, dyskusję oraz heurezę.

Według Słownika terminów literackich przekład intersemiotyczny to określenie stosowane na gruncie semiologii. [...] polega na odtworzeniu danej wypowiedzi za pomocą znaków należących do odmiennego sytemu semiotycznego. Ze względu na odmienność bu-

29 Por. T. Kotarbiński, O pojęciu metody, Warszawa 1957, s. 5; K. Kruszewski, Metoda kształcenia: od zmiany do sposobu jej wywotywania, „Kwartalnik Pedagogiczny” 1982, nr 3-4, s. 55; W. Okoń, Stownik pedagogiczny, Warszawa 1987, s. 174.

30 Stosuje się określenia: metoda, technika, chwyt metodyczny, zabieg, a nawet strategia.

31 Por. K. Lausz, Materiały pomocnicze do nauczania historii literatury, Warszawa 1981, s. 61. 
dowy znaków w różnych systemach konieczne jest zbudowanie odpowiedniego języka pośredniczącego, który umożliwia porównanie elementów i dobór odpowiednich ekwiwalentów ${ }^{32}$.

Z kolei Roman Jakobson wyróżnił trzy możliwości przekładowe: „przekład wewnątrzjęzykowy lub przeredagowywanie (rewording), przekład międzyjęzykowy lub przekład właściwy (translationpoper) oraz przekład intersemiotyczny lub transmutację (transmutation)"33.

Czapczyński przekład intersemiotyczny ${ }^{34}$ traktował szeroko, jego założenia wyrastały bowiem z idei jedności i wielotworzywowości sztuk (materia znaku jak twierdził — nie odgrywała najważniejszej roli przy próbach transmutacji) ${ }^{35}$.

Łódzki polonista za naturalne uznawał współwystępowanie wielu kodów na lekcjach języka polskiego, toteż często proponował zestawianie na zasadzie podobieństwa motywów tekstów literackich z pracami malarskimi. Jego zdaniem w interpretacji dzieła malarskiego wypadało korzystać z terminologii literaturoznawców. Choć nie wyraził tego expresis verbis, można uznać, że pojęcia „interpretować dzieło sztuki” i „czytać obraz” uznawał za synonimiczne. W obydwu wypadkach należało wykonać podobne kroki - deszyfrować poziom znaczeń poszczególnych elementów, ich układów i związków. Nauczyciel, realizując jego propozycje, stawał się przewodnikiem po świecie szeroko rozumianej sztuki (kształcenie estetyczne): fotografii, obrazu, obiektu architektonicznego. Tworząc wraz z uczniami opis konkretnych artefaktów i zestawiając utwór literacki z gotowym dziełem, miał gromadzić właściwe słownictwo (synonimy, antonimy, wyrazy nacechowane emocjonalnie), uczył stosowania peryfraz, słowem - doskonalił umiejętność posługiwania się żywą mową. Dzięki takim ćwiczeniom zapisane w różnych językach sztuki myśli i obrazy przenikały się i wspomagały proces interpretowania sztuki i literatury.

Doskonaleniu mówienia i kształceniu sztuki interpretowania tekstów literackich służyły wykonane przez młodzież rysunki. Ich przydatność w kształceniu polonistycznym łódzki Czapczyński upatrywał w dwu obszarach. po pierwsze umożliwiały one precyzowanie intuicyjnych wrażeń z lektury, po drugie zaś pomagały w czytelniczym zadomowieniu w dziele, docieraniu do jego znaczeń po-

32 T. Kostkiewiczowa, Przekład intersemiotyczny, [hasło w:] Słownik terminów literackich, red. J. Sławiński, Wrocław 2002, s. 446-447.

33 R. Jakobson, Ojęzykoznawczych aspektach przekładu, [w:] W poszukiwaniu istoty języka. Wybór pism, red. M.R. Mayenowa, Warszawa 1989, s. 373.

34 Współcześnie A. Dyduchowa trafnie zauważa, że przekład intersemiotyczny stanowi „dobry sposób przygotowania ucznia do nawiązywania kontaktów z otoczeniem społecznym i kulturowym. Ma istotne znaczenie w języku innych dzieł sztuki korespondujących motywami i stylem z omawianym w klasie utworem literackim, i służy usprawnianiu ich opisu" - eadem, Metody kształcenia sprawności językowej, Kraków 1998, s. 100.

35 Podobne stanowisko wiele lat później zaprezentowała S. Wysłouch, która akcentowała brak teoretycznych uzasadnień na gruncie semiologii o „nieprzekładalności” znaków — por. eadem, Literatura a sztuki wizualne, Warszawa 1994; inaczej twierdzi M. Hopfinger — według badaczki znaki przekładane są tylko częściowo - por. eadem, Adaptacje filmowe utworów literackich. Problemy teorii i interpretacji, Wrocław 1974, s. 83-84. 
przez uważne, refleksyjne wnikanie w tworzywo artystyczne nawet gdy istniała bariera niezbyt wykształconego języka pojęciowego. Stawały się wówczas bądź konkretyzacją przedmiotów zawartych w dziele (plan Soplicowa, rozplanowanie ogrodu Zosi), bądź też plastycznym ekwiwalentem sensów konotowanych przez tekst literacki (na przykład Obraz pól litewskich, Zachód słońca ${ }^{36}$ [nad Soplicowem - M.G.-T.]. Komentowanie własnych prac wymagało od wychowanków dojrzałości emocjonalnej w formułowaniu myśli i przeżyć.

Formą przekładu intersemiotycznego były wypowiedzi analogiczne (synonimiczne) do omawianych na lekcjach (na przykład opis najbliższej okolicy inspirowany opisem wsi/miasta zawartym w czytance). Uczeń „otwierał” się na utwór poprzez wyzwolenie aktywności werbalnej, prowadzącej do pośredniego wypowiadania się o nim poprzez własne działania lub odczucia. W ten sposób pogłębiał akt lektury, poszerzał rozumienie literackich środków ekspresji. Celem działań było zwiększenie swobody operowania zdaniem, przeciwdziałanie sztywności językowej i uświadomienie, że to samo można powiedzieć na wiele sposobów (dobór stosownego słownictwa, stosowanie właściwych konstrukcji składniowych, unikanie powtórzeń). Podobną funkcję pełniły ćwiczenia, w których uczeń przedstawiał treść tekstu z różnych punktów widzenia, wypełniał miejsca niedookreślone, zamieniał mowę pozornie zależną na zależną i odwrotnie.

Kolejną metodą, która zwróciła uwagę Czapczyńskiego, były działania dramowe, choć dydaktyk — jak już wspomniano — nie posłużył się tym terminem. Prezentację metody warto poprzedzić kilkoma uwagami wstępnymi.

Drama jako metoda ${ }^{37}$ wiele zawdzięcza Caldwellowi Cookowi. Przed pierwszą wojną światową w The Perse School w Cambridge ${ }^{38}$ wprowadził on gry sceniczne $^{39}$. Pionierką dramy w Stanach Zjednoczonych była Winifred Ward, która za szczególnie wartościowy aspekt, realizujący społeczne i emocjonalne cele edukacji, uznała analizę charakteru. Zrozumienie odgrywanej postaci przez dziecko ułatwiało — jej zdaniem — formułowanie własnego systemu aksjologicznego

36 T. Czapczyński, Metodyczny rozbiór „Pana Tadeusza” w formie pytań, wyd. 3 zm. i popr. z podtytułem Do użytku w szkołach powszechnych, średnich i seminariach nauczycielskich, Warszawa 1925, s. 146.

37 Źródeł dramy jako sposobu pracy z dzieckiem należy poszukiwać w myśli pedagogicznej J.J. Rousseau i J.H. Pestalozziego.

38 Jego metody opierały się na trzech zasadach: 1. Podstawą wiedzy nie jest słuchanie i czytanie, lecz działanie, gra i doświadczenie. 2 Wysokie efekty pracy są najczęściej rezultatem spontanicznego wysiłku, którego podstawą są autentyczne zainteresowania, nie zaś przymus uczenia się. 3. Spontaniczna gra stanowi naturalny środek nauki w dzieciństwie i w młodości.

39 W latach czterdziestych do angielskich szkół dramę wprowadził P. Slade. Uważał ją za swoistą formę artystyczną i domagał się, by stała się odrębnym przedmiotem na takich samych prawach jak literatura, historia, muzyka czy plastyka. Wyróżnił: grę osobistą, której istotą jest ruch, tendencja do hałasu i fizycznego wysiłku (bieganie, skakanie), i grę zaprojektowaną, w której największą rolę pełni umysł, czyli skłanianie się ku spokojowi i wyciszeniu (czytanie, pisanie, słuchanie muzyki). Kontynuatorem jego poczynań był B. Way, który swoją koncepcję oparł na wykorzystywaniu pięciu zmysłów człowieka: wzroku, słuchu, węchu, smaku i dotyku. 
i pełniejszego poznawania innych ${ }^{40}$. Dramę stosowali John Merill (w nauczaniu języków obcych) i William Wirt (kształcenie wypowiedzi słownych poprzez akcję dramatyczną). Ideę wykorzystania dramy w celach edukacyjnych rozwijał John Dewey. Amerykański pedagog od 1920 roku propagował ,uczenie się przez działanie" (learning by doing) dzięki stosowaniu metody w szkołach podstawowych. Głoszone przez niego hasła „nowego wychowania” korespondowały z nowoczesną szkołą francuską technik Celestina Freineta (twórcze działania artystyczne). Ich istotą było dostosowanie zasad i metod kształcenia do właściwości psychicznych dziecka — potrzeb działania typu funkcjonalnego, opartego na kształceniu zmysłów (Maria Montessori i Ovide Decroly) czy ekspresji twórczej i zabawy (Friedrich Froebel). We Włoszech bezpośrednio do procesu dydaktycznego dramę włączył Claudio Desinan. W Kanadzie ciekawą propozycję edukacji przez dramę przedstawił Richard Courtney ${ }^{41}$. W Polsce uwagę pedagogów pochłaniały: plan daltoński, metoda projektów, metoda ośrodków zainteresowań w powiązaniu z nauczaniem łącznym, uczenie się pod kierunkiem oraz działania dramowe. Z tymi przesłankami korelowały postulaty rozwijania sfery emocjonalnej młodego człowieka, a także zasady indywidualizacji w działaniu dydaktycznym i wychowawczym, zrodzone na gruncie haseł wychowania estetycznego, propagowanych na zjazdach nauczycielskich w Hamburgu, Dreźnie i Weimarze ${ }^{42}$ oraz powtórzonych na Pierwszym Międzynarodowym Kongresie Sztuki w Szkole.

Czapczyński wskazywał, że angażowanie uczuć wychowanków w działania polonistyczne zwiększało efektywność kształcenia. Na wielu płaszczyznach dostrzegał edukacyjne korzyści wchodzenia w rolę bohatera literackiego. Służyło ono między innymi pogłębionej charakterystyce poszczególnych osób, ocenie jej interakcji z innymi, prowadziło do pogłębionej analizy i interpretacji motywów działania i postępowania, kierowało uwagę uczestnika zajęć na okoliczności decyzji podejmowanych przez postaci literackie. W istotny sposób poszerzało krąg dostępnych doświadczeń, wzbogacało wiedzę o świecie zewnętrznym oraz umożliwiało poznawanie świata własnych uczuć i panowania nad emocjami. Taką aktywność przewidywała propozycja wcielenia się w postaci dziewczynki i chłopca oraz służącej, widocznych na rysunku Artura Grottgera (czytanka Bajka). Wychowankowie mogli zrekonstruować opowieść kobiety oraz doznania towarzyszące dzieciom. Również obecnie za cenne można uznać odtworzenie realiów życia młodych ludzi w drugiej połowie XIX wieku, opisanie ich strojów, zrekonstruowanie wyglądu pokoju, przybliżenie wydarzeń, które miały miejsce wcześniej.

40 W. Ward wymienia pięć głównych form aktywności: ruch (pantomima), wrażliwość, charakteryzacja, dialog, formy dramatyczne.

${ }^{41}$ Badacz zaproponował nauczanie trzyetapowe: 1) praca z dziećmi od 5 do 10 lat (poprzez gry dramatyczne inspirowane przez nauczyciela), 2) działania dzieci starszych do 18 lat (gra dramatyczna może być łączona z formami teatralnymi), 3) powyżej 18 lat (dominują spektakle teatralne opierające się na grach dramatycznych).

42 A.S., Trzeci zjazd zwolenników wychowania estetycznego, „Nowe Tory” 1906, z. 5, s. 540 542 . 
Podobny charakter miało zadanie wcielenia się w rolę siedemnastowiecznych uczniów (wspomniany Garnuszek paupra). Z pewnością ciekawy przebieg miały lekcje, podczas których uczniowie odgrywali sceny „z życia kota, psa, kur [...] itp.” (ĆW, 82) ${ }^{43}$. Łódzki pedagog dopuszczał również zamianę zwierzęcych bohaterów bajek na ludzi. Taką sytuację kreowały teksty: Koń $i$ osioł Ignacego Krasickiego oraz Franciszka Morawskiego Osiot i Jacek. Pomocne w realizacji wymienionych ćwiczeń mogły być różne techniki dramowe: rola, rozmowa, kartka mówionego pamiętnika, być może stopklatka czy żywy obraz. Werbalizację wspierały rysunki, a w późniejszym etapie prace pisemne.

Czapczyńskiego należy uznać za jednego z pierwszych propagatorów heurezy. Choć za ojca metody uznaje się Sokratesa ${ }^{44}$, to w szkole metoda zaistniała na początku XX wieku, a rozwinęła się w dwudziestoleciu międzywojennym w ramach koncepcji lekturoznawczej. Jej istotę stanowiły cyklicznie i logicznie ułożone pytania o badawczym charakterze, zadawane przez nauczyciela i/lub uczniów. Pytania szczegółowe, ułatwiające poszukiwanie właściwych rozwiązań, koncentrowały się wokół pytania głównego o charakterze problemowym. Udzielane odpowiedzi powinny być wynikiem samodzielnej pracy wychowanków. By lekcja heurystyczna należycie spełniła swoje zadanie, zdaniem łódzkiego pedagoga należało umiejętnie sformułować pytania (dydaktyk wielokrotnie przestrzegał przed łańcuszkiem zbyt drobiazgowych zadań), uważnie słuchać uczniów, ograniczyć swoją rolę do kierowania rozważaniami wychowanków, nie żądać natychmiastowej odpowiedzi, lecz dać czas na refleksję. Formułę heurystycznego postępowania pokazał Czapczyński w Metodycznym rozbiorze „Pana Tadeusza”... oraz Metodycznym rozbiorze „Ogniem i mieczem”. Należy podkreślić rangę tych niesłusznie zapomnianych dzisiaj publikacji, gdyż stanowiły — mimo iż nie były wolne od usterek - cenne źródło inspiracji dla ówczesnych pedagogów. Przypomnijmy, że przyniosły konkretne rozwiązania praktyczne, w momencie gdy dokonywała się transformacja systemu edukacyjnego, oznaczająca konieczność przejścia od lekcji (systemu) herbartowskiej do lekcji (systemu) deweyowskiej. Nauczyciele posługujący się dotąd wykładem byli zobligowani do stosowania metody poszukującej, opartej na pytaniu dydaktycznym ${ }^{45}$.

W projekcie Czapczyńskiego nie zabrakło również dyskusji, czyli — jak podpowiada łaciński źródłosłów discussio — „roztrząsania” jakiejś sprawy, wymiany zdań na określony temat. Stosowanie tej metody wymagało od uczniów aktywności intelektualnej, werbalnej i recepcyjnej oraz przygotowania do lekcji. Zadaniem prowadzącego dyskusję było dążenie do wypracowania wspólnego stanowi-

43 Przykładowe zadania: Rozpacz starej kotki po zabiciu młodych; Dzień psa łańcuchowego; Wróble w stodole, na dachu - ĆW, 82.

44 Por. M. Łojek, Rodowód i wartości metody problemowej w nauczaniu literatury, Zielona Góra 1976.

45 Por. K. Wojciechowski, S. Szober, B. Nawroczyński, Wskazówki metodyczne do programu gimnazjum państwowego. Język polski (gimnazjum wyższe), Warszawa 1923. 
ska w atmosferze poszanowania adwersarzy, refleksyjnego słuchania odmiennych racji, umiejętności argumentowania własnego stanowiska oraz zdolności do rewidowania prezentowanych sadów. Do dyskusji skłaniały tematy: Zdania Czerwonego Krzyża; Jaka pomoc może okazać wojsku społeczeństwo?; Rola ochotników w obronie Polski (przy omawianiu Reduty Ordona Adama Mickiewicza, kl. V; ĆW, 93); Rola uczucia w życiu młodzieńca, człowieka dojrzałego, starca (przy omawianiu Ody do młodości Mickiewicza, k1. V; ĆW, 102); Która ksiażka wywarła na tobie szczególne wrażenie (inspiracją był Latarnik Henryka Sienkiewicza, kl. V).

Pracując wspomnianymi metodami, uczniowie wykonywali ćwiczenia słownikowo-frazeologiczne, składniowe, stylistyczne, gramatyczne, kompozycyjne i redakcyjne. Dużą wagę łódzki dydaktyk przywiązywał do kultury żywego słowa (estetyczne wygłaszanie, odpowiednie frazowanie, właściwe tempo mówienia, stosowna modulacja głosu, intonacja, stawianie akcentów logicznych itp.). W tym zakresie zalecał nauczycielom podręczniki Juliusza Tennera ${ }^{46}$.

Sprawności językowe Czapczyński pojmował — najogólniej rzecz ujmując — jako zespół łączących się z sobą umiejętności koniecznych do sformułowania wypowiedzi poprawnej pod względem językowym, zrozumiałej, stosownej do tematu i sytuacji mówienia. Miała ona właściwie prezentować pozycję autora oraz jego nastawienie do odbiorcy ${ }^{47}$. Na sprawność językową według dydaktyka składały się: a) sprawność systemowa (gramatyczna), czyli umiejętność tworzenia zdań zgodnie z regułami gramatycznymi; b) sprawność społeczna, czyli umiejętność realizowania różnych ról społecznych przez rozmówców (wymagała wiedzy na temat relacji społecznych panujących w danej grupie); c) sprawność sytuacyjna, czyli umiejętność posługiwania się językiem w różnych sytuacjach komunikacyjnych (na przykład w szkole wobec nauczyciela i kolegów); d) sprawność pragmatyczna, czyli umiejętność osiągania celów przez nadawcę wypowiedzi (zdolność przekazywania informacji o sobie, własnych uczuciach, myślach, ale także zdolność przekonania odbiorcy ${ }^{48}$. Wszystkie wspomniane sprawności lokował w sprawności komunikacyjnej, gdy występowała umiejętność równoczesnego dostrzegania wielu szczegółów, które mogły usprawnić lub zakłócić porozumienie. Tak pojmowany proces komunikowania się zależał zarówno od sprawności językowej nadawcy, jak i odbiorcy. Każdy z tych podmiotów powinien wiedzieć, jak rozumieć cudze i jak tworzyć poprawnie własne komunikaty, jak odróżniać zdania poprawne od zdań niegramatycznych, jak rozpoznawać wieloznaczność słów i konstrukcji, jak wyrażać daną treść na wiele różnych sposobów.

46 J. Tenner, Technika żywego słowa, Lwów-Warszawa 1906; idem, Estetyka żywego stowa, Lwów-Warszawa 1904.

47 Por. W. Pisarek, Sprawność językowa, [hasło w:] Encyklopedia języka polskiego, red. S. Urbańczyk, Wrocław-Warszawa-Kraków 1994, s. 332.

48 Por. S. Grabias, Kultura słowa a sprawności komunikacyjne, „Polonistyka” 1991, nr 7, s. 419-429. Zob. również idem, Język w zachowaniach społecznych. Podstawy socjolingwistyki i logopedii, Lublin 2019. 


\section{Podsumowanie}

Czapczyński, podobnie jak wielu pedagogów międzywojnia, postrzegał człowieka jako osobę, która w słownictwie, składni i frazeologii języka ojczystego nazywała otaczający świat, wyrażała myśli, uczucia i emocje, słowem - układała siebie w narracji tożsamościowej. By ułatwić tworzenie opowieści własnego życia, zaproponował wiele różnorodnych form wypowiedzi, sięgał po ćwiczenia oparte na praktycznym działaniu i przeżywaniu, które zwiększały skuteczność nauczania. Zaprezentowane przez niego ćwiczenia stwarzały okazję do budowania osobniczego stylu. Właściwie prowadzone eksponowały elementy języka stanowiące wyznaczniki indywidualizmu wypowiedzi, zachęcały bowiem do intencjonalnego posługiwania się zasobem środków stylistycznych w zależności od przekazywanych kwestii, przyjmowanej formy, nastawienia emocjonalnego i sytuacji mówienia.

Łódzki dydaktyk przekonywał, że ćwiczenia w mówieniu, uaktywniając wiedzę oraz umiejętności podopiecznych (działania analityczno-interpretacyjne) dzięki zbliżaniu sytuacji lekcyjnych do autentycznych sytuacji komunikacyjnych, w naturalny sposób przygotowywały ich do komunikowania siebie i świata swoich wartości oraz poznawania świata innych. Oponując przeciw ujednolicaniu mowy i pokazywaniu gotowych schematów, za kluczowe z perspektywy systematycznego rozwijania umiejętności językowych uznał uczniowską samodzielność i autonomiczność w działaniach, toteż konsekwentnie upominał się o eksponowanie różnorodności, uświadamianie możliwości i bogactwa języka.

Podejście zadaniowe, właściwe propozycji Czapczyńskiego, sprzyjało kształceniu sprawności językowej. Uczynienie prymatem działań polonisty wymogu częstego używania mówionej polszczyzny tworzyło przestrzeń do rozwijania tej umiejętności w warunkach zbliżonych do naturalnych, dla których istotne były (i są) interakcyjność oraz aktywność w kontaktach (uczenie się w działaniu „mówienie przez mówienie”). Ukierunkowanie procesu nauczania na ucznia umożliwiało młodemu człowiekowi tworzenie swobodnych wypowiedzi, pozytywnie wpływało na samodzielność wychowanków i ich kreatywność, zwiększało motywację do pracy poprzez zaangażowanie w lekcyjne działania. W tym celu łódzki polonista uwzględniał potrzeby i zainteresowania uczących się, a także sięgał po przykłady z codziennego życia, które były dodatkową zachętą do aktywnego włączenia się w wykonywanie zadań. Mierzenie się z sytuacją komunikacyjną ukazywało wychowankom z jednej strony przydatność ćwiczeń, a zatem zasadność podejmowanego przez nich wysiłku podczas jego realizacji, z drugiej zaś mobilizowało do radzenia sobie z rozmaitymi problemami mimo posiadania ograniczonych środków językowych. Ćwiczenia w mówieniu mogły stać się również punktem wyjścia do podjęcia refleksji nad językiem. Wydaje się, że budziły naturalną ciekawość poznawczą i chęć pogłębiania wiedzy oraz poszerzania umiejętności - motywowały młodzież do ciągłego doskonalenia własnych umiejętności komunikacyjnych. 
Czapczyński zakładał, że kompetencje komunikacyjne można kształtować przede wszystkim poprzez komunikowanie się z innymi użytkownikami języka. Można uznać, że przywołane metody — przekład intersemiotyczny, działania dramowe, heureza i dyskusja — kształciły operacje myślowe, krytycyzm, postawę badawczą, samodzielność, motywowały do uczenia się, sprzyjały zapamiętywaniu i utrwalaniu wiedzy. Zachęcały uczniów do aktywności intelektualnej, werbalnej i emocjonalnej. Wiedza, którą młodzież zdobywała przez samodzielne dochodzenie do niej, stawała się jej bliższa i funkcjonalna (wiedziała, jak ją wykorzystać).

Wydaje się, że także obecnie warto stosować propozycje ćwiczeń w mówieniu oferowane przez Czapczyńskiego, dostosowując je do konkretnej sytuacji dydaktycznej i pamiętając o zapewnieniu młodemu człowiekowi możliwości zrównoważonego rozwoju kompetencji językowych.

\section{Bibliografia}

A.S., Trzeci zjazd zwolenników wychowania estetycznego, „Nowe Tory” 1906, z. 5, s. 540-542.

Bogołębska B., Czapczyński Tadeusz (1884-1958), [w:] Stownik badaczy literatury polskiej, red. J. Starnawski, Łódź 1994, s. 55-61.

Chrzanowski I., Wojciechowski K., Wypisy polskie dla klas wyższych szkót średnich (kl. VIIVIII), Lwów 1913.

Czachowska J., Czapczyński Tadeusz, [w:] Współcześni polscy pisarze i badacze literatury. Słownik biobibliograficzny, oprac. J. Czachowska, A. Szałagan, t. 2, Warszawa 1994, s. 80-82.

Czapczyński T., Ćwiczenia w mówieniu. Przyczynek do metodyki języka polskiego, Warszawa 1922. Czapczyński T., Idzie sobie bobas mały, Łódź 1948.

Czapczyński T., Książeczka trochę nowa, trochę stara o Magdzie, mące, kluskach i zegarach, Kraków 1942.

Czapczyński T., Metodyczny rozbiór „Pana Tadeusza” w formie pytań, wyd. 3 zmien. i popraw. z podtyt. Do użytku w szkołach powszechnych, średnich i seminariach nauczycielskich, Warszawa 1925.

Czapczyński T., Pamiętam... Poezje, Łódź 1937.

Czapczyński T., Pierwszy ustęp w klasie pierwszej, „Przyjaciel Szkoły” 1924, nr 13, s. 270-272; nr 14, s. 296-300.

Dańcewiczowa J., Dydaktyka mówienia i pisania jako działu nauczania języka ojczystego, [w:] Encyklopedia wychowania, t. 2, Warszawa [1936], s. 290-299.

Dyduchowa A., Metody kształcenia sprawności językowej, Kraków 1998.

Dżugaj J., O ćwiczeniach w mówieniu, „Przyjaciel Szkoły” 1931, nr 9, s. 347-351.

Gajak-Toczek M., Franciszek Próchnicki (1847-1911) dydaktyk - edytor - badacz literatury, Łódź 2010.

Gajak-Toczek M., Język domostwem bycia - o funkcjonalnym nauczania polszczyzny w podręcznikach dla nauczycieli Tadeusza Czapczyńskiego, „Kształcenie Językowe” 16, 2018, s. 9-28.

Gajak-Toczek M., Tadeusz Czapczyński. Pedagog — literaturoznawca - literat, Łódź 2017.

Grabias S., Język w zachowaniach społecznych. Podstawy socjolingwistyki i logopedii, Lublin 2019.

Hopfinger M., Adaptacje filmowe utworów literackich. Problemy teorii i interpretacji, Wrocław 1974.

Jakobson R., O językoznawczych aspektach przekładu, [w:] W poszukiwaniu istoty języka. Wybór pism, red. W.M. Mayenowa, Warszawa 1989, s. 372-381. 
Kostkiewiczowa T., Przekład intersemiotyczny, [hasło w:] Słownik terminów literackich, red. J. Sławiński, Wrocław 2002, s. 446-447.

Kotarbiński T., O pojęciu metody, Warszawa 1957.

Kruszewski K., Metoda ksztatcenia: od zmiany do sposobu jej wywoływania, „Kwartalnik Pedagogiczny" 1982, nr 3-4, s. 37-62.

Kuziak M., Rzepczyński S., Jak pisać?, Bielsko-Biała 2005.

Kwaskowska W., Jak realizowałam ćwiczenia w mówieniu i pisaniu, „Polonista” 1937, s. 46-49.

Lausz K., Materiaty pomocnicze do nauczania historii literatury, Warszawa 1981.

Łojek M., Rodowód i wartości metody problemowej w nauczaniu literatury, Zielona Góra 1976.

Okoń W., Stownik pedagogiczny, Warszawa 1987.

Prądy w nauczaniu języka ojczystego, red. S. Szober, Warszawa 1908.

Program nauki w państwowym liceum ogólnokształcacym z polskim językiem nauczania (tymczasowy). Język polski, Lwów 1937.

Program nauki w publicznych szkołach powszechnych trzeciego stopnia z polskim językiem nauczania (tymczasowy). Ministerstwo Wyznań i Oświecenia Publicznego, Lwów 1934.

Program szkoły powszechnej jednoklasowej czterooddziałowej i dwuklasowej cztero- i pięciooddziałowej. Cz. III. Język Polski. Ministerstwo Wyznań i Oświecenia Publicznego, Warszawa 1918.

Próchnicki F., Wskazówki do nauki języka polskiego, Lwów 1885.

Próchnicki F., Wojciechowski K., Wypisy polskie dla szkót średnich, Lwów 1911 (kl. IV-V).

Reiter M., Czytania polskie (kl. I-III), Lwów 1910-1912.

Skulski R., Ćwiczenia w mówieniu jako postulat ogólnopedagogiczny w szkole średniej, [w:] Pamiętnik I Ogólnopolskiego Zjazdu Polonistów w Warszawie w dniach 24, 25, 26 kwietnia 1924 r., oprac. W. Kopczewski, Lwów-Warszawa 1925, s. 102-107; przedruk: „Muzeum” 1925, z. 1-2, s. 102-107.

Skwarczyńska S., Tadeusz Czapczyński (1884-1958), „Prace Polonistyczne” 1960, seria 16, s. 229 232.

Szyszkowski W., Bibliografia metodyki nauczania języka polskiego 1918-1939, Warszawa 1963.

Tenner J., Estetyka żywego stowa, Lwów-Warszawa 1904.

Tenner J., Technika żywego słowa, Lwów-Warszawa 1906.

Urbański A., O lepsze wyniki ćwiczeń w mówieniu, Przyjaciel Szkoły” 1937, nr 16, s. 631-635.

Wojciechowski K., Szober S., Nawroczyński B., Wskazówki metodyczne do programu gimnazjum państwowego. Język polski (gimnazjum wyższe), Warszawa 1923.

Wysłouch S., Literatura a sztuki wizualne, Warszawa 1994. 